\title{
Environmental and anthropogenic impacts on intra-specific variation in leatherback turtles: opportunities for targeted research and conservation
}

\author{
Bryan P. Wallace ${ }^{1,2, *}$, Vincent S. Saba ${ }^{3}$ \\ ${ }^{1}$ Center for Applied Biodiversity Science, Conservation International, 2011 Crystal Drive, Suite 500, Arlington, \\ Virginia 22202, USA \\ ${ }^{2}$ Nicholas School of the Environment and Earth Sciences, Duke University Marine Lab, 135 DUML Road, Beaufort, \\ North Carolina 28516, USA \\ ${ }^{3}$ Virginia Institute of Marine Science, College of William and Mary, Rt. 1208 Greate Road, Gloucester Point, \\ Virginia 23062, USA
}

\begin{abstract}
Intra-specific variation in life history traits and/or population trends provides 'natural experiments' to identify causes of observable differences among populations of organisms. Geographically widespread marine species, for example, can experience variation in both environmental and anthropogenic impacts across their ranges that can differentially influence expression of life history traits and population dynamics in separate populations. For example, body size and reproductive output differences among geographically separate, conspecific populations of leatherback turtles Dermochelys coriacea have been linked to variations in environmentally driven resource availability, which differentially affect the resilience of leatherback populations to anthropogenic pressures. Specifically, differences in life history traits and population trends among breeding populations of leatherbacks that forage in the eastern Pacific versus Atlantic Ocean reflect the variable nature of resource availability in the eastern Pacific. These environmentally driven life history differences have contributed to divergent population responses to anthropogenic sources of mortality. In this review, we provide a synoptic view of this body of research and conclude with strategic recommendations for future research and conservation initiatives. This approach has implications for other widely distributed marine species with variations in life history traits that make them more susceptible to humandriven population declines.
\end{abstract}

KEY WORDS: Life history variation · Conservation strategies · Marine turtles · Leatherback turtles · Anthropogenic impacts · Environmental variability $\cdot$ Resource availability $\cdot$ El Niño Southern Oscillation

- Resale or republication not permitted without written consent of the publisher

\section{INTRODUCTION}

Life history traits and population trends can be altered by fluctuating environmental conditions, as well as by anthropogenic factors operating on relevant spatio-temporal scales. Certain ecological and life history traits make species less resilient to effects of environmental and/or human impacts, and thus more susceptible to population declines (Musick 1999, Powles et al. 2000). Specifically, differences in morphometric and reproductive parameters, or in population structure or growth rates among breeding populations of the same species, provide a 'natural experiment' that can reveal differential effects of environmental conditions or anthropogenic impacts, or both (Jennings \& Beverton 1991, Frederiksen et al. 2005, Wallace et al. 2006a, Saba et al. 2008a,b, Suryan et al. in press). Thus, the specific driver or suite of drivers of diver- 
gence among conspecifics can be identified by studying relevant biological information (e.g. vital population rates, energy budgets, spatio-temporal habitat use) on conspecific populations in a comparative context. These practices have conservation applications where management strategies can be tailored to address a unique scenario of impacts that threaten the persistence of a particular segment of a species.

In marine ecosystems, widely distributed species can experience variation in oceanographic conditions in different parts of their range that can be manifested in observable differences in life history traits (Suryan et al. in press). For example, differences in reproductive traits between Atlantic herring Clupea harengus populations have been associated with phenotypic plasticity in response to differing environmental conditions across this species' geographic range (Jennings \& Beverton 1991). In black-tailed kittiwakes Rissa tridactyla, conspecific populations exhibit differences in the tradeoff between adult survivorship and seasonal fecundity, which appears to reflect relative stability of environmental conditions at different foraging sites (Frederiksen et al. 2005). Furthermore, fluctuating oceanographic conditions due to large-scale climate phenomena such as the El Niño-Southern Oscillation (ENSO) and the North Atlantic Oscillation (NAO) can have observable impacts on primary productivity and resource abundance and/or distribution in the oceans (Chavez et al. 1999, 2003, Stenseth et al. 2002). Strong ENSO episodes in the Pacific Ocean influence reproduction of sea turtles (Limpus \& Nicholls 1988, Saba et al. 2007), drive foraging movements of large predators like tuna (Lehodey et al. 1997), and can cause population declines in pinnipeds (Trillmich \& Limberger 1985) and seabirds (Schreiber \& Schreiber 1984). Thus, for species whose geographic distributions include areas with high rates of climate variability, and/or variation in biophysical and biogeochemical characteristics that influence resource availability, differences in life history traits and population dynamics are possible.

Like environmental conditions, impacts of human activities on natural systems and populations can vary in time and space. Major anthropogenic pressures on marine ecosystems include pollution and habitat degradation, resource extraction, and fishing (i.e. both over-exploitation of target species and unsustainably high levels of bycatch), but none of these factors acts uniformly on marine systems. Rowell et al. (2008) described the compounded impacts of habitat alteration and overfishing on the life history and population declines in the totoaba Totoaba macdonaldi, a fish species endemic to the upper Gulf of California. While overfishing has depleted totoaba abundance, disruption of high-quality habitat following construction of a dam resulted in slowed first-year growth rates and delayed age to maturity compared to those traits prior to the dam construction (Rowell et al. 2008). In particular, long-term effects of overfishing can result in fisheries-induced selection for accelerated maturation time, smaller body size at sexual maturity, lower fecundity, particular behavioral phenotypes, etc. (Law 2000, Heino \& Godø 2002). In addition, unsustainable fishing practices have driven population declines in sharks (Ferretti et al. 2008) and seabirds (Tuck et al. 2001), but to different degrees depending on geographic distribution of different population segments. Thus, differences in various life history or population traits between geographically separated but taxonomically related animals could occur due to differences in anthropogenic impacts on the marine environment.

While deciphering the specific impacts of environmental or anthropogenic factors on the life history and demography of animal populations can be difficult, characterizing the interaction between the two is even more challenging. To explore this issue more thoroughly, we take a case study approach using leatherback turtles Dermochelys coriacea. Leatherbacks are considered critically endangered according to the IUCN Red List (Sarti Martínez 2000), but this global status belies important differences among populations of leatherbacks in different ocean basins. Specifically, leatherbacks in the eastern Pacific (EP), on average, are the smallest in body size and exhibit the lowest reproductive output of any population in the world (Table 1) (Saba et al. 2008a, b). Moreover, leatherbacks in the Pacific Ocean have declined in numbers in recent decades, whereas many leatherback populations in the Atlantic Ocean are stable or even increasing (Fossette et al. 2008) (Fig. 1). Recently, several studies have focused on discerning the drivers of these inter-population differences, with the aim of applying the findings to population-specific conservation strategies. We provide a synoptic view of this body of research and posit several important questions to guide future research into intra-specific drivers of life history and population trend differences among leatherback populations and to foster targeted conservation strategies aimed at enhancing population recoveries.

\section{ENVIRONMENTAL IMPACTS}

Variability in oceanographic conditions that affect resource availability and reproductive physiology can influence life history traits and population dynamics of sea turtles (Bjorndal 1982, Limpus \& Nicholls 1988, Hays 2000, Chaloupka 2002, Solow et al. 2002, Saba et al. 2008b). In particular, high variability in resource availability can be manifested in delayed remigration 
Table 1. Dermochelys coriacea. Population size, life history, energy requirement, resource availability differences between eastern Pacific and western Atlantic leatherbacks. Data are based on studies by Wallace et al. (2006a), Saba et al. (2008b), Santidrián Tomillo et al. (2007), and Dutton et al. (2005) and are primarily from 2 rookeries, but patterns are representative of populations from each basin. See Saba et al. (2008b) for a more extensive table that includes information from other leatherback populations around the world. CCL: curved carapace length; NPP: net primary productivity; $\mathrm{Tg}=10^{12} \mathrm{~g}$

\begin{tabular}{|c|c|c|c|c|c|c|c|}
\hline Population & $\begin{array}{l}\text { Population size } \\
\text { (females } \mathrm{yr}^{-1} \text { ) }\end{array}$ & $\begin{array}{c}\text { Estimated } \\
\text { adult survivor- } \\
\text { ship }\left(\% \mathrm{yr}^{-1}\right)\end{array}$ & $\begin{array}{c}\mathrm{CCL} \\
(\mathrm{cm} \pm \mathrm{SD})\end{array}$ & $\begin{array}{c}\text { Reproductive } \\
\text { energy cost } \\
\left(10^{3} \mathrm{~kJ}\right)\end{array}$ & $\begin{array}{c}\text { Required } \\
\text { feeding rate } \\
\left(\mathrm{kg} \mathrm{d}^{-1}\right)\end{array}$ & $\begin{array}{c}\text { Foraging } \\
\text { area NPP } \\
(\mathrm{Tg} \text { C per } 12 \mathrm{~d})\end{array}$ & $\begin{array}{l}\text { Reproductive } \\
\text { output (eggs fe- } \\
\text { male }^{-1} \text { per } 5 \text { yr) }\end{array}$ \\
\hline Eastern Pacific & $200-800$ & 78 & $144.5 \pm 1.7$ & 4900 & $87^{\mathrm{a}}$ & 3.3 & 500 \\
\hline Western Atlantic & $10000-20000$ & 89 & $154.2 \pm 0.7$ & 6300 & $141^{\mathrm{b}}$ & 12.5 & 1050 \\
\hline
\end{tabular}
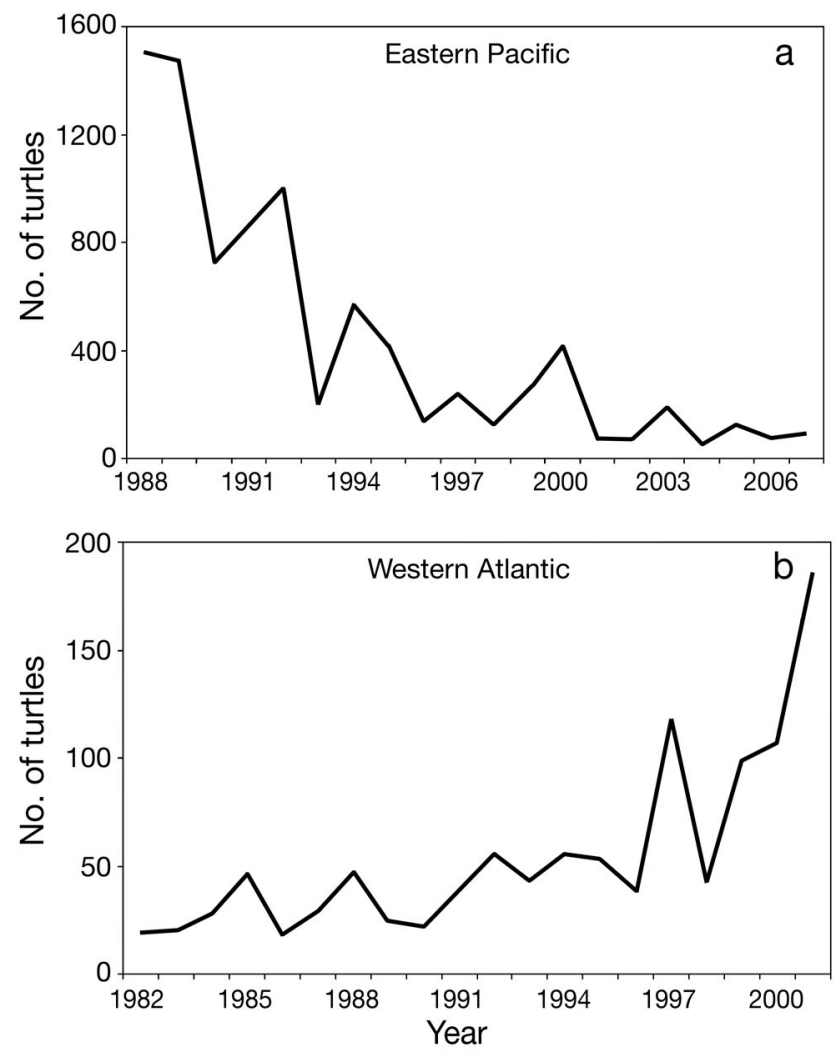

Fig. 1. Dermochelys coriacea. Population trends at representative nesting beaches in; (a) the eastern Pacific (Parque Nacional Marino Las Baulas, Costa Rica; P. Santidrián Tomillo, G. Blanco, J. R. Spotila, \& F. V. Paladino unpubl. data) and (b) the western Atlantic (Sandy Point National Wildlife Refuge, St. Croix, US Virgin Islands; Dutton et al. 2005)

of sea turtles to breeding areas, as well as in high interannual variability in overall numbers of nesting turtles (Hays 2000, Broderick et al. 2001). The influence of environmental variability on life history traits of conspecific populations has been studied particularly well for leatherbacks Dermochelys coriacea. Oceanic net primary productivity (NPP), the base of the marine food web, in the foraging areas of EP leatherbacks
(Morreale et al. 1996, Eckert \& Sarti 1997, Shillinger et al. 2008) is affected by ENSO events every 3 to $7 \mathrm{yr}$ (Chavez et al. 1999) and by multi-decadal variability every 20 to 30 yr (Chavez et al. 2003). Although leatherbacks feed on gelatinous zooplankton and not on the lowest trophic levels represented by NPP measurements, high NPP levels are commonly used as proxies for high consumer biomass and complex trophic dynamics (Saba et al. 2008a,b). When the sea surface temperature (SST) of the tropical EP is cooler than usual (La Niña phase of ENSO), NPP is typically enhanced and the reproductive frequency of EP leatherbacks increases (Saba et al. 2007); the opposite holds true during the warm El Niño phase. The influence of ENSO has been observed among several other populations of sea turtle species in the Pacific Ocean (Limpus \& Nicholls 1988, Chaloupka 2001, Chaloupka et al. 2008b). In the Atlantic Ocean, model estimates of NPP in the foraging areas of Atlantic leatherbacks is more stable and, in some areas, at a higher rate (Saba et al. 2008b). Thus, EP leatherbacks probably encounter variable resource distribution and abundance more frequently than do Atlantic leatherbacks.

Hypothesizing that differences in resource availability might be responsible for life history differences between leatherback populations in the EP and western Atlantic Ocean (WA) (Table 1), Wallace et al. (2006a) calculated the reproductive energy requirements for EP leatherbacks and WA leatherbacks in order to compare estimates of the energy intake rates necessary to sustain the distinct traits of the 2 populations. These energy budget comparisons revealed that, if resource availability were similar in foraging areas for both populations, energy costs and thus the time required for EP leatherbacks to acquire sufficient energy to undertake reproduction (i.e. remigration interval) were actually lower than those values for their WA counterparts, in contrast to the observed pattern (EP remigration interval $=3.7 \mathrm{yr}$, Reina et al 2002, Santidrián Tomillo et al. 2007; WA remigration interval $=2$ to 3 yr Dutton et al. 2005, Rivalan et al. 
2005; Table 1). For the observed remigration intervals to occur, WA leatherbacks must consume $>60 \%$ more energy per day on average than EP leatherbacks, according to energy budget estimates (Wallace et al. 2006a). Moreover, EP leatherbacks could effectively halve their remigration intervals (from $\sim 4$ to $2 \mathrm{yr}$ ) through relatively modest increases in energy intake rates (i.e. $\sim 20 \mathrm{~kg} \mathrm{~d}^{-1}$ ). Price et al. (2006) reported that delayed remigration by leatherbacks to Costa Rican nesting beaches resulted in no apparent increase in reproductive output or in growth rates, leading the authors to conclude that remigration for reproduction occurs after a leatherback reaches a threshold level of energy acquisition. Given these observations, Wallace et al. (2006a) concluded that differential resource availability renders EP leatherbacks unable to match the morphometric and reproductive traits of WA leatherbacks.

However, the Wallace et al. (2006a) study was largely speculative and did not incorporate estimates of differences in resource availability. Using rigorous quantitative procedures, historical data, and innovative analytical tools, recent studies have confirmed that leatherback reproduction and differences among leatherback populations worldwide is governed by variation in oceanographic conditions. Saba et al. (2007) demonstrated that fluctuations of the ENSO in the Pacific Ocean influence the remigration probability of leatherbacks, and thus the seasonal nesting cohort size, at Playa Grande, Costa Rica. Reina et al. (2009) also showed intra-individual variation in remigration intervals among leatherbacks that was related to the ENSO. Furthermore, Saba et al. (2008a) modeled patterns of NPP in the tropical EP and showed that putative foraging areas that determine the nesting response of leatherbacks are characterized by highly variable resource conditions in the tropical EP, which likely explains delayed remigration and other traits of EP leatherbacks (Wallace et al. 2006a). Stable isotope analyses of tissues from leatherbacks in both the Pacific and the Atlantic Oceans showed that distinct oceanographic processes influence trophic dynamics on foraging grounds of EP versus WA leatherbacks (Wallace et al. 2006b). Finally, Saba et al. (2008b) linked observed variation in reproductive output and body size among leatherback populations worldwide to significant differences in total NPP, as well as the degree to which it fluctuates, across putative foraging areas for each population. In particular, NPP in EP foraging areas is highly variable in space and in time, whereas foraging areas of other leatherback populations (e.g. North Atlantic) have more stable and even higher levels of NPP (Table 1). Taken together, this suite of studies demonstrates the strong connection between variation in environmental conditions and variation in leatherback life history traits worldwide. Further research to elucidate the migratory and foraging behaviors of leatherbacks should include spatiotemporal characterization of gelatinous zooplankton abundances and distributions (e.g. Houghton et al. 2006), as well as meta-analyses of leatherback satellite-tracking studies from which it is possible to infer behavioral patterns consistent with foraging versus migration (Hays et al. 2006, Jonsen et al. 2007, Bailey et al. 2008).

\section{ANTHROPOGENIC IMPACTS}

Not only do conspecific leatherback Dermochelys coriacea populations vary with respect to life history traits, but they also vary in terms of population trends (Fig. 1). Over the past 2 decades, leatherback nesting colonies in the EP have declined by nearly $90 \%$ (Santidrián Tomillo et al. 2007, Sarti Martínez et al. 2007). Leatherbacks nesting in the western Pacific have declined as well, but to a lesser extent than their EP counterparts (Hitipeuw et al. 2007, but see Chan \& Liew 1996). Meanwhile, populations in the WA (Dutton et al. 2005) and elsewhere (Hughes 1996) are generally stable or increasing (Fossette et al. 2008, but see Troëng et al. 2004). Certain sources of anthropogenic mortality occur in all leatherback populations: early stage (i.e. eggs and hatchlings) mortality due to egg harvest and coastal development and late stage (i.e. adults and sub-adults) mortality due to fisheries bycatch and directed harvest (i.e. hunting). While multiple factors have almost certainly contributed to these divergent population trajectories, the particular combination of drivers remains unclear.

The enormous and prolonged effects of comprehensive egg harvest have been demonstrated for several sea turtle populations. Nearly complete egg harvest has impacted leatherbacks in the Pacific Ocean, where both the Costa Rican and Mexican colonies suffered egg harvest levels of nearly $90 \%$ for perhaps 2 decades (Sarti Martínez et al. 2007, Santidrián Tomillo et al. 2008), and Malaysian leatherbacks appear to have been extirpated (Chan \& Liew 1996). Relocation of eggs laid in areas of high risk of developmental failure (e.g. below the natural high tide line, near beach access points) to enhance hatchling production appears to have little to no effect on population dynamics of EP leatherbacks because only $10 \%$ of all eggs laid by this depleted nesting population are in need of relocation (Santidrián Tomillo et al. 2008). In contrast, nearly half of all egg clutches laid on beaches on St. Croix, US Virgin Islands (Caribbean), are relocated, and this large increase over natural hatchling production has contributed to an exponential increase in the 
number of nesting leatherbacks $\sim 15$ yr later (Dutton et al. 2005). Furthermore, Dutton et al. (2005) cited the timing of the observed increase in new adult female recruits at St. Croix as potential support for an estimated age to maturity for leatherbacks of 12 to $15 \mathrm{yr}$ (Zug \& Parham 1996). However, it is unclear whether juvenile growth rates or age at maturity vary among leatherback populations due to inter-basin differences in resource availability, which might also be driving the distinct population responses (Saba et al. 2008b).

Not only has early-stage survivorship been enhanced, but annual adult survivorship appears to be considerably higher for WA leatherbacks (Dutton et al. 2005, Rivalan et al. 2005) than for EP leatherbacks (Santidrián Tomillo et al. 2007), which might also have contributed to the divergence in population trends. Historically unsustainable egg harvest coupled with low adult survivorship $\left(78 \% \mathrm{yr}^{-1}\right)$ for the Costa Rica population (Santidrián Tomillo et al. 2007) indicates that the chances of population recovery are slim if adult mortality is not decreased (Santidrián Tomillo et al. 2008). It is important to note that these adult mortality rates are based purely on nesting return rates and are subject to uncertainty. In addition, Sarti Martínez et al. (2007) pointed out that, despite having produced roughly the same number of hatchlings through conservation efforts in Mexico as had been produced at St. Croix (Dutton et al. 2005), an increase in nesting female numbers has yet to occur on Mexican beaches. Thus, it appears that differences in historic and current early stage (egg and hatchling) survivorship between EP and WA has played a role, at least in part, in the distinct responses of the 2 leatherback populations, but that high adult survivorship is necessary for population recovery in leatherbacks. Similarly, despite the historical depletion of green turtle Chelonia mydas populations around the globe, nesting beach conservation efforts - with concomitant declines in mortality of late stage turtles - have resulted in increasing numbers of nesting females in recent years at various study sites worldwide (Chaloupka et al. 2008a). These examples show that improving early stage survivorship can be important, but that high adult survivorship is a requisite for population recovery in sea turtles.

Fisheries bycatch is also a hazard for sea turtle populations worldwide (e.g. Lewison et al. 2004), but bycatch impacts on these populations vary according to spatiotemporal overlap in fisheries operations and critical ontogenetic habitat, as well as according to characteristics of fishing gear (Wallace et al. 2008). The observed discrepancy between annual adult mortality rates of WA versus EP leatherback populations (Dutton et al. 2005, Rivalan et al. 2005, Santidrián Tomillo et al. 2007) (Table 1) might be due in part to differing degrees of bycatch mortality (Troëng et al. 2004). The current Atlantic leatherback bycatch situation consists of industrial longline and trawl fisheries that operate throughout the North Atlantic and incidentally capture several hundred leatherbacks annually, but leatherback mortality in these fisheries is quite low (Watson et al. 2005). In contrast, nearshore fisheries in the EP, specifically driftnets targeting swordfish off Chile and Peru, are thought to have incidentally killed thousands of leatherbacks annually in the 1980s and early 1990s, and this source of mortality probably contributed greatly to the observed declines on EP nesting beaches (Eckert \& Sarti 1997, Kaplan 2005). It is worth noting that despite extremely high mortality rates in gillnet bycatch off Trinidad (Lum 2006), the leatherback population nesting there is among the largest in the world (Eckert 2006). If high bycatch in coastal gillnets contributed to the decline in EP leatherbacks, this should serve as a cautionary tale for the Trinidad situation, where currently high bycatch mortality might be a 'population time bomb', which might result in a future population decline (Seminoff \& Shanker 2008). However, despite the impacts on leatherback populations described above, no hypothetical scenario has been described to explain the sudden and simultaneous collapse of leatherback nesting colonies throughout the EP. Given the lack of a clear pattern in effects of egg harvest and fisheries bycatch impacts for leatherbacks worldwide, inter-population differences in mortality patterns might not be the only causes for differences in leatherback population trajectories.

\section{SYNERGISTIC EFFECTS OF ENVIRONMENTAL AND ANTHROPOGENIC IMPACTS}

As illustrated above, both environmental and anthropogenic factors affect leatherbacks Dermochelys coriacea worldwide, but how these factors differ and interact geographically has important implications for patterns in the variation of life history and population dynamics of globally distributed sea turtle species. Marine species with similar life history traits to sea turtles (e.g. slow to mature, long-lived) tend to be more susceptible to extinction risk from anthropogenic pressures (Musick 1999, Powles et al. 2000). Along these lines, Wallace et al. (2006a) and Saba et al. (2008a,b) concluded that resource limitation renders EP leatherbacks unable to match the body size and reproductive output of leatherbacks from other regions, and hypothesized that the resource-driven decrease in reproductive frequency makes EP leatherbacks less resilient to anthropogenic pressures, such as fisheries bycatch and egg harvest. This 'one-two punch' of resource limitation making EP leatherbacks more susceptible to anthropogenic hazards than other popula- 
tions has likely resulted in the divergent population trends in the 2 basins during the past 2 decades. In fact, phylogenetic analyses suggest an evolutionary history of extinction and recent recolonization of populations of all sea turtle species in the EP, including leatherbacks, perhaps revealing historic vulnerability of sea turtles to ephemeral oceanographic regimes in the EP (Bowen \& Karl 2007).

When we consider the complete biology and population ecology of leatherbacks, the effects of the interaction between environmental and anthropogenic factors become clearer. In addition to the differences in morphometrics, reproductive output, and population dynamics, there are apparent behavioral differences between EP leatherbacks and other leatherback nesting stocks with respect to post-nesting migration strategies. Leatherbacks leaving reproduction areas in the WA exhibit several migratory routes across the North Atlantic Ocean to putative foraging areas on the North American continental shelf off Nova Scotia, Canada, and in the northeastern USA, the pelagic North Atlantic, the western European shelf, and on the west coast of Africa (Hays et al. 2004, James et al. 2005, Eckert 2006). Likewise, leatherbacks nesting in Papua, Indonesia and Papua New Guinea, also show multiple migratory behaviors, with routes to the South China Sea, the Sulu and Sulawesi Seas between Australia and New Zealand, and across the Pacific to the west coast of North America (Benson et al. 2007b). In contrast, EP leatherbacks demonstrate a persistent migratory pattern on a S to SW heading into the Southeast Pacific Subtropical Gyre and Humboldt Current region off South America (Morreale et al. 1996, Eckert \& Sarti 1997, Shillinger et al. 2008). This monotypic migratory phenotype could make EP leatherbacks more vulnerable to environmental variability affecting resource availability and threats on their foraging grounds when compared to the diverse phenotypes exhibited by leatherbacks in other parts of the world (Dutton 2006).

While all other leatherback populations exhibit a migratory strategy to foraging areas near coastlines during non-reproductive periods, EP leatherbacks appear to migrate almost solely to oceanic areas after nesting. However, coastal areas in the EP are characterized by consistently high levels of NPP, in contrast to the relatively barren Southeast Pacific Subtropical Gyre, to which post-nesting leatherbacks tend to migrate (Saba et al. 2008a). Similarly, gelatinous zooplankton are often abundant in coastal areas (e.g. Houghton et al. 2006), and, with only a few exceptions (e.g. Doyle et al 2008), scyphozoan jellyfish generally have a coastal distribution. In addition, most coastal areas might be easier to access, given their closer proximity to nesting beaches and the reduced influence of major equatorial ocean currents closer to shore. For these reasons, Saba et al. (2008a) surmised that these coastal areas are plausible leatherback foraging grounds. In fact, Eckert \& Sarti (1997) tracked a few individuals to coastal areas off Peru and Chile, and Shillinger et al. (2008) reported that one individual from Costa Rica spent the entirety of her $>500 \mathrm{~d}$ track in coastal waters off Costa Rica and Panama.

Most of the world's fishing effort is in the form of artisanal fisheries in coastal areas, and these activities can have enormous impacts on marine megafaunal populations (e.g. Jaramillo-Legorreta et al. 2007, Peckham et al. 2007). Previous studies have reported extremely high bycatch mortality rates of leatherbacks in nearshore driftnets targeting swordfish off Peru and Chile (Frazier \& Montero 1990, Eckert \& Sarti 1997), and leatherback bycatch continues to occur in Peruvian (Alfaro-Shigueto et al. 2007) and Chilean waters (Donoso \& Dutton 2007). Taking all of the above into account, Saba et al. (2008a) hypothesized that the observed lack of diversity in migration patterns exhibited by EP leatherbacks might reflect the impact of historically high rates of fisheries bycatch in coastal areas having essentially eliminated this behavioral phenotype from the population. Similarly, persistently high bycatch of multiple shark species in the Mediterranean Sea resulted in the sequential depletion first of coastal shark populations followed by pelagic populations, which mirrored the expansion of fishing operations from nearshore to offshore areas (Ferretti et al. 2008).

As Saba et al. (2008a) pointed out, for this scenario to be possible, EP leatherbacks would have to demonstrate a high degree of foraging site fidelity, which has been reported for other sea turtle species (Broderick et al. 2007). James et al. (2005) reported return migrations by adult and subadult leatherbacks from breeding areas in the Caribbean to foraging grounds in Nova Scotia, Canada, where they had been tagged originally. Recaptures of leatherbacks foraging in Monterey Bay, California, across years have also been reported (Benson et al. $2007 \mathrm{c}$ ). Therefore, although the source of variation in leatherback migratory behaviors remains unclear, foraging site fidelity is apparently a shared trait among leatherback populations and those of other sea turtle species. Future tagging studies on previously tracked individuals would be necessary to demonstrate foraging site fidelity for EP leatherbacks to support the idea of intra-population behavioral polymorphisms and the selection against coastal migration in EP leatherbacks. In addition, because previous tracking studies of postnesting female leatherbacks only described the first year or two of the entire $\sim 4$ yr remigration period (e.g. Shillinger et al. 2008), tracking leatherbacks from foraging areas in the southeastern Pacific back toward their nesting beaches, as has been done in the Atlantic (e.g. James et al. 2005), should be a research priority. 
If the hypothesis by Saba et al. (2008a) is correct, and 'coastal migrants' have been removed from the EP population due to strong selection pressure from coastal fisheries through bycatch mortality, this may also have contributed to the observed differences between EP and WA leatherbacks. If coastal foraging areas are more predictable and productive, and are less energetically costly to exploit, leatherbacks that foraged in these areas might have benefited from shorter remigration intervals, as well as enhanced energy allocation to other reproductive (e.g. clutch sizes) and morphometric (e.g. body size) parameters. It is possible that the low frequency of shorter remigration intervals ( 2 yr) in the EP leatherback population (Santidrián Tomillo et al. 2007) reflects the loss of coastally foraging turtles. Thus, the long average and wide range of remigration intervals ( 4 and 2 to $11 \mathrm{yr}$, respectively) for EP leatherbacks likely reflect the patchy and unpredictable nature of resource availability driven by ENSO in the tropical EP, and the poor foraging quality in the Southeast Pacific Subtropical Gyre experienced by the remaining leatherbacks in this population. A possible analogy to this scenario was reported by Caut et al. (2008), who used stable isotope analyses to assign leatherbacks from 1 nesting colony in French Guiana to 2 distinct foraging groups that differed according to their remigration intervals. Similarly, in a Japanese nesting rookery of loggerhead turtles Caretta caretta, individual turtles with 3 yr remigration intervals were associated with relatively poorer quality foraging grounds and prey availability, while turtles with 2 yr remigration intervals occupied higher quality foraging habitats (Hatase \& Tsukamoto 2008). Thus, variation in environmental conditions, differences in migratory strategies among individual leatherbacks, and anthropogenic pressures can be manifested in observed differences in life history traits within and among conspecific populations.

Although major differences have been highlighted in oceanographic conditions in recent years on leatherback foraging areas worldwide, a multi-decadal perspective sheds light on historical periods when EP foraging areas probably were more favorable for leatherbacks (Saba et al. 2008b). These periods, ranging from 20 to $30 \mathrm{yr}$ in duration, reflect shifting temperature regimes in the EP as forced by climate between warmer ('El Viejo') and cooler ('La Vieja') conditions, which have also been associated with dramatic changes in marine food webs in the EP (Chavez et al. 2003). In particular, when SST is cooler than usual in the EP (i.e. 'La Vieja'), NPP is higher, leading to favorable conditions in EP leatherback foraging areas (Saba et al. 2007). However, the aforementioned population trends and life history traits of nesting leatherbacks in the EP have been observed primarily during a warm regime in the EP (i.e. 'El Viejo'), which is associated with lower NPP and thus less favorable conditions in leatherback foraging areas (Saba et al. 2008b). Therefore, it is plausible that life history traits of EP leatherbacks would be more similar to those of WA turtles when EP foraging areas are in a cool, 'La Vieja' regime. Moreover, if the reproductive output of EP turtles were to increase during a 'La Vieja' regime, this population's vulnerability to anthropogenic mortality would be reduced, thus possibly resulting in some degree of population recovery (Saba et al. 2008b).

Despite the speculative nature of this scenario, anecdotal information about historic trends in leatherback nesting in the region, in addition to more recent, rigorously collected population data (e.g. Santidrián Tomillo et al. 2007, Sarti Martínez et al. 2007), can provide valuable insights into the potential influence of the 'La Vieja-El Viejo' phenomenon. According to local people living near the important leatherback nesting beaches in the EP, relatively few nesting leatherbacks were observed prior to the 1950s in Costa Rica (i.e. Playa Grande; B. P. Wallace \& R. Piedra Chacón unpubl. data) and Mexico (i.e. Mexiquillo; A. L. Sarti Martínez pers. comm.), in contrast to the thousands of individual leatherbacks nesting in these places by the 1970s. The apparent EP leatherback population increase from low numbers prior to 1950 to extremely high numbers in the 1970s coincided with virtually non-existent anthropogenic impacts and 'La Vieja' conditions in the EP that would have been more favorable to leatherback resource acquisition, reproductive investment, and high survivorship (Saba et al. 2008b). In contrast, the regime shift to less favorable (for leatherbacks) 'El Viejo' conditions in the EP that occurred in the 1970 s provided the environmental backdrop for the onset and persistence of the strong anthropogenic pressures of egg collection and fisheries bycatch on EP leatherbacks for the past $20 \mathrm{yr}$. Thus, it is reasonable to speculate that this combination of ' $\mathrm{El}$ Viejo' and unsustainably high sources of mortality might be the previously unidentified 'smoking gun' that caused the swift and simultaneous collapse of nesting rookeries throughout the EP. Thus, just as ENSO-driven variation in resource availability has made EP leatherbacks more vulnerable to anthropogenic impacts than other populations of leatherbacks around the world, we hypothesize that longterm changes in leatherback populations are related to the multi-decadal oceanographic regimes in the EP. Extending this idea to an even longer historical time scale, genetic analyses have revealed that repeated expansions and contractions of both the size and geographic range of the EP leatherback populations have apparently occurred in recent evolutionary history due to climatic fluctuations in this region (Bowen \& Karl 
2007). Clearly, these ideas are speculative and require further monitoring of nesting populations throughout future climate regimes in the EP, but also suggest that resource conditions-and, in turn, population trendsfor EP leatherbacks could improve in the future if conservation efforts are successful in reducing or eliminating unsustainable anthropogenic sources of mortality.

\section{OTHER EXAMPLES}

It is important to point out that intra-specific differences among long-lived marine vertebrate species related to anthropogenic and environmental factors are almost certainly not unique to leatherbacks Dermochelys coriacea. For example, commercial whaling reduced populations of grey whales Eschrichtius robustus worldwide during the first half of the 20th century, resulting in extirpation of the North Atlantic Ocean population and severe depletion of populations in the western and eastern Pacific (Powles et al. 2000). After whaling pressures were eliminated, the eastern Pacific grey whale population rebounded and was eventually removed from the USA List of Endangered and Threatened Species in 1994 (Buckland \& Breiwick 2002). In contrast, the western Pacific population was listed as critically endangered on the IUCN Red List due to its failure to recover, possibly due to effects of continued hunting (Weller et al. 2002). In addition to human threats to grey whales, observations of apparently emaciated and undernourished grey whales have increased on both sides of the Pacific, implicating decreased prey abundance resulting from fluctuating environmental conditions on feeding grounds (Weller et al. 2002, Moore et al. 2003). In response to changes in resource availability on historically important foraging grounds in Alaska, grey whales in the eastern Pacific appear to have expanded their foraging range (Moore et al. 2003), thus bolstering their resilience to impacts on population dynamics. However, resource limitation might be hindering the recovery of western Pacific grey whales by increasing their susceptibility to other sources of mortality, such as hunting by humans and boat strikes (Buckland \& Breiwick 2002, Weller et al. 2002).

Differences in life history traits and population trends also exist among conspecific seabird populations. Frederiksen et al. (2005) described variation in adult survivorship, fecundity, and population growth rates of black-tailed kittiwakes among 9 breeding populations across the Atlantic and Pacific Oceans, apparently following patterns of environmental variability among feeding areas of different populations (Frederiksen et al. 2005). Weimerskirch (2002) also reported higher survivorship among European seabird popula- tions at more northerly latitudes. Furthermore, Tuck et al. (2001) reported that differences in trends among conspecific populations of the wandering albatross Diomedea exulans were due to spatial variation in severity of fisheries bycatch across the geographic range of the species. As in the case of leatherback turtle populations, differences between populations of other marine megafaunal species reveal the roles of variation in environmental conditions and human impacts. These examples underscore the importance of inter-population comparisons of life history characteristics and population dynamics of other widely distributed species.

\section{OPPORTUNITIES FOR TARGETED RESEARCH AND CONSERVATION}

Identification of the unique suite of drivers that are manifested in observed differences in the life history traits and population dynamics of conspecifics inhabiting distinct geographic areas is important for informing effective, population-specific conservation efforts. In the case of leatherbacks, human pressures have played an indisputable role in inter-population differences, but the relative impact of anthropogenic perturbations to leatherback Dermochelys coriacea populations has likely been exacerbated by differences in environmentally driven resource availability among marine habitats inhabited by leatherbacks worldwide (Wallace et al. 2006a, Saba et al. 2007, 2008a,b). Specifically, relatively superior, more consistent environmental (resource) conditions have likely contributed to the stability and increases observed in leatherback nesting populations in the North Atlantic Ocean over the past 2 decades. In contrast, declines in leatherback populations in the Pacific Ocean, particularly in the EP, have occurred in the 'seascape' of variable resource availability, which has diminished the resilience of these populations to anthropogenic sources of mortality, specifically high rates of fisheries bycatch and egg harvest.

Conservation efforts that have reduced anthropogenic sources of mortality have resulted in positive population growth rates in several sea turtle populations (e.g. Dutton et al. 2005, Chaloupka et al. 2008a). Thus, when anthropogenic perturbations are removed or reduced to sustainable levels, sea turtles appear to be less sensitive to environmental variability and can recover from historic depletion. However, because rapid population increases are not realistic, due to sea turtle life history traits (Musick 1999), conservation actions must remain in place for several decades to achieve significant signs of recovery. Mitigating human impacts like egg harvest and incidental capture 
in fishing gear requires swift and effective action, but it is also important to take into account the compounding effect of environmental conditions on sea turtle populations (Chaloupka 2002, Saba et al. 2007, Chaloupka et al. 2008b). Thus, dual impacts of environmental and anthropogenic impacts present a unique challenge for conservation efforts.

Our review of intra-specific variation in leatherback life history traits and population trends enables us to make several recommendations for targeted research and conservation strategies. First, current beach protection at the major nesting complexes in Mexico and Costa Rica is successfully minimizing anthropogenic impact on hatchling production (i.e. egg harvest). However, the growing threats from to unsustainable coastal development in the EP, particularly in Costa Rica (B. P. Wallace \& R. Piedra Chacón unpubl. data), mean that beach protection efforts must be redoubled to ensure the viability of critical leatherback nesting habitats. Second, given the importance of conspecific variation in life history traits and the status of population trends, assessments of globally distributed sea turtle species (i.e. IUCN Red List Assessments) should evaluate extinction risk based on biologically relevant distinctions among geographically separate populations (Seminoff \& Shanker 2008). This realignment of assessment units will allow for more realistic, appropriate conservation recommendations for sea turtles worldwide. Third, population models that project future trajectories for vulnerable sea turtle populations, such as EP leatherbacks, should incorporate environmental effects, particularly in terms of reproduction parameters (e.g. remigration interval), in order to generate more realistic long-term population projections under various scenarios of mortality patterns and conservation strategies (Chaloupka 2002, Saba et al. 2007, Chaloupka et al. 2008b). Fourth, further research is necessary to characterize behavior and habitat use of leatherbacks in feeding areas and during remigrations to breeding areas in relation to oceanographic conditions and prey distribution and abundance (e.g. James et al. 2005, Houghton et al. 2006), particularly in the EP.

Finally, fisheries managers could apply information from population models and satellite tracking studies that incorporate environmental data to create adaptive guidelines for fishing fleets in areas inhabited by leatherbacks in response to local environmental conditions. In this scenario, limits on allowable leatherback bycatch would be adjusted according to environmental conditions on leatherback foraging grounds in the southeastern Pacific (Shillinger et al. 2008). An exemplary approach along these lines, TurtleWatch, has been implemented to mitigate bycatch of loggerhead turtles in the Hawaiian pelagic longline fishery (Howell et al. 2008). Specifically, for recovery of the coastal foraging cohort of EP leatherbacks, we suggest that conservation efforts be targeted along the west coastline of South America, where leatherbacks are presently being caught as bycatch in gillnet and other fisheries (Alfaro-Shigueto et al. 2007, Donoso \& Dutton 2007). If leatherback bycatch in these fisheries can be reduced significantly or eliminated entirely, the restoration of a coastal foraging cohort could occur given enough time. Recovery of this foraging strategy would likely decrease the EP population's sensitivity to ENSO events by increasing the number of 2 and 3 yr remigrants, especially during warm El Niño phases. Although this scenario is hypothetical, reducing leatherback mortality along the coastline of South America would undoubtedly benefit the entire EP population.

We acknowledge that the creation and implementation of such approaches are extremely complicated. Nonetheless, given the critically imperiled status of EP leatherbacks, conservation management must address the distinct circumstances facing this population relative to those of other leatherback populations. Likewise, for other widely distributed marine species with environmentally driven life history traits that make them more susceptible to anthropogenically driven population declines, we recommend similar interpopulation comparisons to make strategic recommendations for future research and to aid conservation priority setting.

Acknowledgements. We thank J. A. Seminoff, M. P. Santidrián Tomillo, and A. L. Sarti Martínez for helpful discussions that improved the manuscript. We also thank G. C. Hays and 2 anonymous reviewers for helpful comments on a previous version of the manuscript.

\section{LITERATURE CITED}

Alfaro-Shigueto J, Dutton PH, Van Bressem MF, Mangel J (2007) Interactions between leatherback turtles and Peruvian artisanal fisheries. Chelonian Conserv Biol 6:129-134

Bailey H, Shillinger G, Palacios D, Bograd S, Spotila J, Paladino F, Block B (2008) Identifying and comparing phases of movement by leatherback turtles using state-space models. J Exp Mar Biol Ecol 356:128-135

Benson SR, Dutton PH, Hitipeuw C, Samber B, Bakarbessy J, Parker D (2007a) Post-nesting migrations of leatherback turtles (Dermochelys coriacea) from Jamursba-Medi, Bird's Head Peninsula, Indonesia. Chelonian Conserv Biol 6:150-154

Benson SR, Kisokau KM, Ambio L, Rei V, Dutton PH, Parker D (2007b) Beach use, internesting movement, and migration of leatherback turtles, Demochelys coriacea, nesting on the north coast of Papua New Guinea. Chelonian Conserv Biol 6:7-14

Benson SR, Forney KA, Harvey JT, Carretta JV, Dutton PH $(2007 \mathrm{c})$ Abundance, distribution, and habitat of leatherback turtles (Dermochelys coriacea) off California, 1990-2003. Fish Bull (Wash DC) 105:337-347 
Bjorndal KA (1982) The consequences of herbivory for the life history pattern of the Caribbean green turtle, Chelonia mydas. In: Bjorndal KA (ed) Biology and conservation of sea turtles. Smithsonian Institution Press, Washington, DC, p 111-116

Bowen BW, Karl SA (2007) Population genetics and phylogeography of sea turtles. Mol Ecol 16:4886-4907

Broderick AC, Godley BJ, Hays GC (2001) Trophic status drives inter-annual variability in nesting numbers of marine turtles. Proc R Soc Lond B Biol Sci 268: 1481-1487

Broderick AC, Coyne MS, Fuller WJ, Glen F, Godley BJ (2007) Fidelity and over-wintering of sea turtles. Proc R Soc Lond B Biol Sci 274:1533-1538

Buckland ST, Breiwick JM (2002) Estimated trends in abundance of eastern Pacific gray whales from shore counts (1967/68 to 1995/96). J Cetacean Res Manag 4:41-48

Caut S, Guirlet, Angulo E, Das K, Girondot M (2008) Isotope analysis reveals foraging dichotomy for Atlantic leatherback turtles. PLoS ONE 3:e1845 doi:10.1371/journal.pone.0001845

Chaloupka M (2001) Historical trends, seasonality and spatial synchrony in green sea turtle egg production. Biol Conserv 101:263-279

Chaloupka M (2002) Stochastic simulation modelling of southern Great Barrier Reef green turtle population dynamics. Ecol Model 148:79-109

Chaloupka M, Bjorndal KA, Balazs GH, Bolten AB and others (2008a) Encouraging outlook for recovery of a once severely exploited marine megaherbivore. Glob Ecol Biogeogr 17:297-304

Chaloupka M, Kamezaki N, Limpus C (2008b) Is climate change affecting the population dynamics of the endangered Pacific loggerhead sea turtle? J Exp Mar Biol Ecol 356:136-143

Chan EH, Liew HC (1996) Decline of the leatherback population in Terengganu, Malaysia. Chelonian Conserv Biol 2:196-203

Chavez FP, Strutton PG, Friederich GE, Freely RA, Feldman GC, Foley DG, McPhaden MJ (1999) Biological and chemical response of the equatorial Pacific to the 1997-98 El Niño. Science 286:2126-2131

Chavez FP, Ryan J, Lluch-Cota SE, Niquen-C M (2003) From anchovies to sardines and back: multidecadal change in the Pacific Ocean. Science 299:217-221

Donoso M, Dutton P (2007) Distribución, abundancia relativa y origen del stock de tortugas marinas capturadas incidentalmente en la flota palangrera chilena de pez espada. XII Congresso Latino-Americano de Ciencias do Mar, Florianopolis

Doyle TK, De Haas H, Cotton D, Dorschel B and others (2008) Widespread occurrence of the jellyfish Pelagia noctiluca in Irish coastal and shelf waters. J Plankton Res 30:963-968

Dutton PH (2006) Geographic variation in foraging strategies of leatherback populations: A hedge against catastrophy? In: Frick M, Panagopoulou A, Rees AF, Williams K (eds) Book of abstracts of the 26th Annual Symposium on Sea Turtle Biology and Conservation. International Sea Turtle Society, Athens, p 189

Dutton DL, Dutton PH, Chaloupka M, Boulon RH (2005) Increase of a Caribbean leatherback turtle Dermochelys coriacea nesting population linked to long-term nest protection. Biol Conserv 126:186-194

Eckert SA (2006) High-use areas for Atlantic leatherback sea turtles (Dermochelys coriacea) as identified using satellite telemetered location and dive information. Mar Biol 149:1257-1267

Eckert SA, Sarti L (1997) Distant fisheries implicated in the loss of the world's largest leatherback nesting population. Mar Turtle Newsl 78:2-7

Ferretti F, Myers RA, Serena F, Lotze H (2008) Loss of large predatory sharks from the Mediterranean Sea. Conserv Biol 22:952-964

Fossette S, Kelle L, Girondot M, Goverse E and others (2008) The world's largest leatherback rookeries: a review of conservation-oriented research in French Guiana/Suriname and Gabon. J Exp Mar Biol Ecol 356:69-82

Frazier J, Montero JLB (1990) Incidental capture of marine turtles by the swordfish fishery at San Antonio, Chile. Mar Turtle Newsl 49:8-13

> Frederiksen M, Harris P, Wanless S (2005) Inter-population variation in demographic parameters: A neglected subject? Oikos 111:209-214

> Hatase H, Tsukamoto K (2008) Smaller longer, larger shorter: energy budget calculations explain intrapopulation variation in remigration intervals for loggerhead sea turtles (Caretta caretta). Can J Zool 86:595-600

> Hays GC (2000) The implications of variable remigration intervals for the assessment of population size in marine turtles. J Theor Biol 206:221-227

$>$ Hays GC, Houghton JDR, Myers AE (2004) Endangered species-Pan-Atlantic leatherback turtle movements. Nature 429:522

Hays GC, Hobson VJ, Metcalfe JD, Righton D, Sims DW (2006) Flexible foraging movements of leatherback turtles across the North Atlantic Ocean. Ecology 87:2647-2656

Heino M, Godø OR (2002) Fisheries-induced selection pressures in the context of sustainable fisheries. Bull Mar Sci 70:639-656

Hitipeuw C, Dutton PH, Benson S, Thebu J, Bakarbessy J (2007) Population status and internesting movement of leatherback turtles, Dermochelys coriacea, nesting on the northwest coast of Papua, Indonesia. Chelonian Conserv Biol 6:28-36

- Houghton JDR, Doyle TK, Wilson MW, Davenport J, Hays GC (2006) Jellyfish aggregations and leatherback turtle foraging patterns in a temperate coastal environment. Ecology 87:1967-1972

Howell EA, Kobayashi DR, Parker DM, Balazs GH, Polovina JJ (2008) TurtleWatch: a tool to aid in the bycatch reduction of loggerhead turtles Caretta caretta in the Hawaii-based pelagic longline fishery. Endang Species Res 5:267-278

Hughes GR (1996) Nesting of the leatherback turtle (Dermochelys coriacea) in Tongaland, KwaZulu-Natal, South Africa, 1963-1995. Chelonian Conserv Biol 2:153-168

James MC, Myers RA, Ottensmeyer CA (2005) Behavior of leatherback sea turtles, Dermochelys coriacea, during the migratory cycle. Proc R Soc Lond B Biol Sci 272: 1547-1555

Jaramillo-Legorreta A, Rojas-Bracho L, Brownell RL Jr, Read AJ, Reeves RR, Ralls K, Taylor BL (2007) Saving the vaquita: immediate action, not more data. Conserv Biol 21: 1653-1655

Jennings S, Beverton RJH (1991) Intraspecific variation in the life history tactics of Atlantic herring (Clupea harengus L.). ICES J Mar Sci 48:117-125

Jonsen ID, Myers RA, James MC (2007) Identifying leatherback turtle foraging behaviour from satellite telemetry using a switching state-space model. Mar Ecol Prog Ser 337:255-264

Kaplan IC (2005) A risk assessment for Pacific leatherback turtles (Dermochelys coriacea). Can J Fish Aquat Sci 62: $1710-1719$

Law R (2000) Fishing, selection, and phenotypic evolution. ICES J Mar Sci 57:659-668

Lum LL (2006) Assessment of incidental sea turtle catch in the 
artisanal gillnet fishery in Trinidad and Tobago, West Indies. Appl Herpetol 3:357-368

Lehodey P, Bertignac M, Hampton J, Lewis A, Picaut J (1997) El Niño Southern Oscillation and tuna in the western Pacific. Nature 389:715-718

Lewison RL, Freeman SA, Crowder LB (2004) Quantifying the effects of fisheries on threatened species: the impact of pelagic longlines on loggerhead and leatherback sea turtles. Ecol Lett 7:221-231

> Limpus CJ, Nicholls N (1988) The Southern Oscillation regulates the annual numbers of green turtles (Chelonia mydas) breeding around northern Australia. Aust Wildl Res 15:157-161

> Moore SE, Grebmeier JM, Davies JR (2003) Gray whale distribution relative to forage habitat in the northern Bering Sea: current conditions and retrospective summary. Can J Zool 81:734-742

Morreale SJ, Standora EA, Spotila JR, Paladino FV (1996) Migration corridor for sea turtles. Nature 384:319-320

Musick JA (1999) Ecology and conservation of long-lived marine animals. Am Fish Soc Symp 23:1-10

> Peckham SH, Maldonado Díaz D, Walli A, Ruíz G, Crowder LB, Nichols WJ (2007) Small-scale fisheries bycatch jeopardizes endangered Pacific loggerhead turtles. PLoS One 2:e1041

Powles H, Bradford MJ, Bradford RG, Doubleday WG, Innes S, Levings CD (2000) Assessing and protecting endangered marine species. ICES J Mar Sci 57:669-676

Price ER, Wallace BP, Reina RD, Spotila JR, Paladino FV, Piedra R, Vélez E (2006) Size, growth, and reproductive output of adult female leatherbacks Dermochelys coriacea. Endang Species Res 1:41-48 (previously ESR 5:1-8), doi: 10.3354/esr001041

Reina RD, Mayor PA, Spotila JR, Piedra R, Paladino FV (2002) Nesting ecology of the leatherback turtle, Dermochelys coriacea, at Parque Nacional Marino Las Baulas, Costa Rica: 1988-1989 to 1999-2000. Copeia 2002:653-664

Reina RD, Spotila JR, Paladino FV, Dunham AE (2009) Changed reproductive schedule of eastern Pacific leatherback turtles Dermochelys coriacea following the 1997-98 El Niño to La Niña transition. Endang Species Res. doi:10.3354/esr00098 (preprint 2008)

Rivalan P, Prevot-Julliard AC, Choquet R, Pradel R, Jacquemin B, Girondot M (2005) Trade-off between current reproductive effort and delay to next reproduction in the leatherback sea turtle. Oecologia 145:564-574

> Rowell K, Flessa KW, Dettman DL, Román MJ, Gerber LR, Findley LT (2008) Diverting the Colorado River leads to a dramatic life history shift in an endangered marine fish. Biol Conserv 141:1138-1148

Saba VS, Santidrián Tomillo P, Reina RD, Spotila JR, Musick JA, Evans DA, Paladino FV (2007) The effect of the El Niño Southern Oscillation on the reproductive frequency of eastern Pacific leatherback turtles. J Appl Ecol 44:395-404

Saba VS, Shillinger GL, Swithenbank AM, Block BA, Spotila JR, Musick JA, Paladino FV (2008a) An oceanographic context for the foraging ecology of eastern Pacific leatherback turtles: consequences of ENSO. Deep-Sea Res I 55:646-660

Saba VS, Spotila JR, Chavez FP, Musick JA (2008b) Bottomup and climatic forcing on the worldwide population of leatherback turtles. Ecology 89:1414-1427

Santidrián Tomillo P, Veléz E, Reina RD, Piedra R, Paladinos FV, Spotila JR (2007) Reassessment of the leatherback turtle (Dermochelys coriacea) nesting population at Parque
Nacional Marino Las Baulas, Costa Rica: effects of conservation efforts. Chelonian Conserv Biol 6:54-62

Santidrián Tomillo P, Saba VS, Piedra R, Paladino FV, Spotila JR (2008) Effects of illegal harvest of eggs on the population decline of leatherback turtles in Las Baulas Marine National Park, Costa Rica. Conserv Biol 22: 1216-1224

Sarti Martinez AL (2000) Dermochelys coriacea. In: IUCN 2008. 2008 IUCN Red List of Threatened Species. www. iucnredlist.org (Accessed on 27 February 2009)

Sarti Martínez L, Barragán AR, Muñoz DG, García N, Huerta P, Vargas F (2007) Conservation and biology of the leatherback turtle in the Mexican Pacific. Chelonian Conserv Biol 6:70-78

Schreiber RW, Schreiber EA (1984) Central Pacific seabirds and the El Niño Southern Oscillation perspectives. Science 225:713-716

Seminoff JA, Shanker K (2008) Marine turtles and IUCN Red Listing: a review of the process, the pitfalls, and novel assessment approaches. J Exp Mar Biol Ecol 356: 52-68

Shillinger GL, Palacios DM, Bailey H, Bograd SJ and others (2008) Persistent leatherback turtle migrations present opportunities for conservation. PLoS Biol 6:e171

Solow AR, Bjorndal KA, Bolten AB (2002) Annual variation in nesting numbers of marine turtles: the effect of sea surface temperature on re-migration intervals. Ecol Lett 5: $742-746$

Stenseth NC, Mysterud A, Hurrell JW, Chan KS, Lima M (2002) Ecological effects of climate fluctuations. Science 297:1292-1296

Suryan RM, Saba VS, Wallace BP, Hatch SA, Frederiksen M, Wanless S (in press) Environmental forcing on life history strategies: evidence for multi-trophic level responses at ocean basin scales. Prog Oceanogr

Trillmich F, Limberger D (1985) Drastic effects of El Niño on Galapagos pinnipeds. Oecologia 67:19-22

> Troëng S, Chacon D, Dick B (2004) Possible decline in leatherback turtle Dermochelys coriacea nesting along the coast of Caribbean Central America. Oryx 38:395-402

Tuck GN, Polacheck T, Croxall JP, Weimerskirch H (2001) Modelling the impact of fishery by-catches on albatross populations. J Appl Ecol 38:1182-1196

Wallace BP, Kilham SS, Paladino FV, Spotila JR (2006a) Energy budget calculations indicate resource limitation in eastern Pacific leatherback turtles. Mar Ecol Prog Ser 318:263-270

Wallace BP, Seminoff JA, Kilham SS, Spotila JR, Dutton PH (2006b) Leatherback turtles as oceanographic indicators: stable isotope analyses reveal a trophic dichotomy between ocean basins. Mar Biol 149:953-960

Wallace BP, Heppell SS, Lewison RL, Kelez S, Crowder LB (2008) Impacts of fisheries bycatch on loggerhead turtles worldwide inferred from reproductive value analyses. J Appl Ecol 45:1076-1085

- Watson JW, Epperly SP, Shah AK, Foster DG (2005) Fishing methods to reduce sea turtle mortality associated with pelagic longlines. Can J Fish Aquat Sci 62:965-981

Weimerskirch H (2002) Seabird demography and its relationship with the marine environment. In: Schreiber EA, Burger J (eds) Biology of marine birds. CRC Press, Boca Raton, FL, p 115-135

Weller DW, Burdin AM, Würsig B, Taylor BL, Brownell RL Jr (2002) The western gray whale: a review of past exploitation, current status, and potential threats. J Cetacean Res Manag 4:7-12

Zug GR, Parham JF (1996) Age and growth in leatherback turtle, Dermochelys coriacea (Testudines: Dermochelyidae): a skeletochronological analysis. Chelonian Conserv Biol 2:244-249 